\title{
SOIL WATER REPELLENCY IN CHINA AND ISRAEL: SYNTHESIS OF OBSERVATIONS AND EXPERIMENTS
}

\author{
LIU, F. ${ }^{*}-$ ZHAN, Y. \\ Faculty of Forestry, Central South University of Forestry and Technology \\ Changsha, Hunan 410004, China \\ *Corresponding authors \\ e-mail: Liufl680@126.com; phone: +86-1597-4170-413 (Liu, F.) \\ e-mail: 752523727@qq.com; phone: +86-1597-4219-341 (Zhan, Y.)
}

(Received $8^{\text {th }}$ Mar 2019; accepted $21^{\text {st }}$ May 2019)

\begin{abstract}
Study of soil water repellency (SWR) has been very systematized in Europe and America but underdeveloped in Asia. This study aims to comprehensively and systematically analyze SWR in China and Israel, and to contribute to the knowledge on SWR in the world. We collected all documents about SWR that were published in China. Research sites were all over the China and typical areas of Israel. 4647 datasets were obtained from these documents. We have done a rounded analysis based on the influencing factors like soil type, soil depth, land type, interference type. Through the data collection and analysis, we found most of the soil in China and Israel is water-repellent, and almost all of the soil types are water-repellent. However, most of the soil types only have low water repellency. The level of soil water repellency of different soil types is different. The soil in forest ecosystem generally has a higher water repellency than that in the non-forest ecosystem. SWR will increase after the interference of water or fire, and the effect of water is more significant. The results provide theoretical basis for soil improvement and vegetation restoration in China and Israel even the World.
\end{abstract}

Keywords: water repellency, fire disturbance, soil type, forest ecosystem, external disturbance

\section{Introduction}

Soil water repellency has perplexed people for almost one century. Soil water repellency is mainly caused by organic hydrophobic matter which originated from plants, external disturbance, and microbial activities, resulting soil hard to be wetted or wet soil difficult to be wetted again after drying. It is pervasive and prevalent to evaluate SWR by Bisdom classification (1993) (Bisdom et al., 1993; Sunny et al., 2018), using water drop penetration time (WDPT): wettable soil $(<5 \mathrm{~s})$, good for wettability; slightly water repellent (5-60 s), decreasing water holding capacity (Doerr et al., 2000; Hossain et al., 2019); strongly water repellent (60-600 s), resulting uneven water infiltration and potential risk to groundwater polluted (Bogner et al., 2008; Ali et al., 2018); severely water repellent (600-3600 s), and extremely water repellent (>3600 s), causing severe soil erosion, environmental damage, and economic loss (Craswell and Lefroy, 2001; Sharjeel et al., 2019).

The climate of China and Israel are different, there is no Mediterranean climate in China. China and Israel are completely different in rainfall characteristics but both of their water resources are uneven distribution. SWR is an important index in soil health evaluation system. The water conservation capacity of soil is weak because of the SWR; this lead to the water cannot be conservation well by soil. China and Israel are facing available water crisis. There have no researches evaluated the soil quality of China and Israel according to the SWR. Our research filled the gap and supplied data of SWR of China and Israel for world SWR database. And our research can also provide reference to soil quality evaluate in other areas. 
China, as a principle Asian country, the SWR researches began in the 1990s (Ebelhar et al., 2008; Tao, 2018). The scientists paid little attention on the correlative studies which started late and lacked of deep research. Only a few simple introductions that lacked of standard, unified and comprehensive analysis could be found in the existing documents discussing about SWR determination methods (Crockford et al., 1991; Liang and Wenshun, 2019), the influential factors of desert SWR (Dahlgren et al., 2008) and the influences of fire disturbance on forest SWR (Chesworth et al., 2008) etc. All terrains types and agrotypes could be discovered in China where had a large range of altitude (-154-8844.43 m), a high precipitation disparity of different regions (5.9-1600 $\mathrm{mm})$, different climate and a big regional heterogeneity. Israel has typical Mediterranean climate and the research of SWR in desert soil in Israel is developed. The comprehensive and objective research on Chinese and Israel SWR hasn't been reported.

By collecting the existing research data, for the first time, the Chinese and Israel's SWR records were combined and analyzed, and unified the calibration of the data unit and classification by utilizing various international standards. Research 1) the overall distribution characteristics of Chinese and Israel's SWR; and 2) the integrated characteristics of Chinese and Israel's SWR.

\section{Materials and Methods}

\section{The database}

This study had collected and sorted out all published SWR documents in China. The data screening work had complied with the following requirements: (1) The experiment design had no obvious flaws. This study did not probe into the uncertainty of different measurement, only took WDPT as a measurement and quantitative index of SWR. (2) Include WDPT measurement data. (3) The properties of the variables in the experiment were related to the temporal or spatial distribution patterns, the control experiment variables like the contact angle between soil and water were excluded. We extracted original information such as geographic information (longitude, latitude, altitude and so on), time (experimental time), land use (vegetation cover type, vegetation type, vegetation composition etc.), soil information (soil type, soil depth etc.), and interference (interference types) from each document. Moreover, some literature data were published in the form of pictures. According to the ordinary way, we intercepted these pictures and employed image analysis software (DigitizeIt, version 1.5.8 http://www.digitizeit.de/) to digitize the data and recover it to the raw data. Great efforts were devoted to data standardized after extraction: (1) WDPT data was unified in second. (2) As for the researches did not mention the specific experiment time, we could reasonably calculate the experiment time according to the data published time. (3) The classification of the land use and ecological regions were based on Hou Hsioh-yu's classification of natural ecological regions in China in 1988. (4) The identification and classification of soil types referred to the soil classification system of the Food and Agriculture Organization of the United Nations (FAO). Compared the soil samples with the data in Chinese Soil Database and the World Soil Database on the basis of the soil background and soil name of those sampling sites to identify the standard names, then contrasted with FAO 85 and FAO 90 to screen and determine the accurate classification of the sample soil by the FAO standard. 
In this study, we arranged 4647 data regarding with all SWR data in China and Israel. At first, We mapped and visualized the spatial and temporal distribution of WDPT data there (Fig. 1, Fig. S1). The research sites were across Chinese provinces in the western, northern, central, southern area and Israel and the research time were span from the earliest WDPT reports in 2009 to 2016.

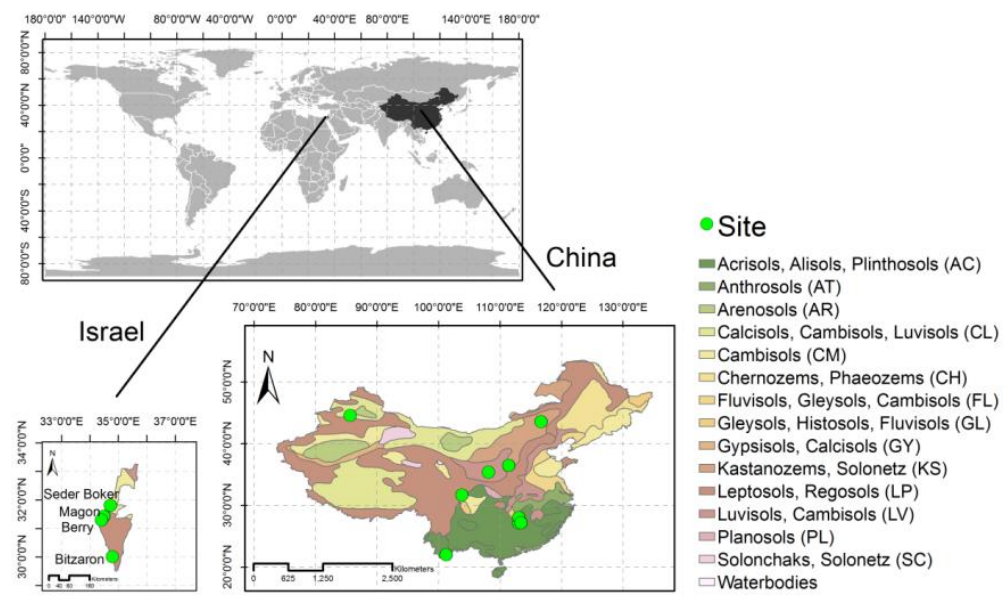

Figure 1. Geographic distributions and sites of data collected. The map on the top is the location of sampling countries in the world. Two maps below are location and Soil backgrounds of sampling sites in China and Israel. Green points represent the location of the sampling sites of data. The background of the soil type distributions were obtainable from the FAO web page

(http://www.fao.org/AG/agL/agll/wrb/soilres.stm), to process soil map backgrounds using ArcGIS9.3 at a scale of 1:25000 000(WRB2003). The soil classification follows world reference base for soil resources (FAO 1990)

4 different environment gradients were set: (1) Land use, including forest ( $\mathrm{n}=970$ ) and non - forest (grassland and farmland, $\mathrm{n}=3673$ ), had 8 different natural ecological periods and more than 20 forest types such as Cunninghamia lanceolata plantation, Pinus massoniana plantation and Schima superba mixed forest (Table 1). (2) Soil type, contained 8 soil types, that were Aeolian soils $(n=288)$, Calcisols $(n=72)$, Red earth $(n=62)$, Red-yellow earth $(n=260)$, Gray-brown desert soil $(n=100)$, Yellow-brown earth $(\mathrm{n}=3529)$, Castano-cinnamon soil $(\mathrm{n}=44)$, Regosols $(\mathrm{n}=288)$ (Table 2). (3) Soil depth, can be reduced to 2 levels, topsoil $(0-5 \mathrm{~cm}, \mathrm{n}=4439)$ and subsoil (depth> $5 \mathrm{~cm}, \mathrm{n}=204)$. (4) Processing gradients, no processing $(n=3807)$, sewage irrigation $(n=528)$, fire disturbance $(\mathrm{n}=308)$.

\section{Statistical analysis}

In this study, WDPT data were logarithmically (Log10WDPT) normalized. We divided the data into five grades according to the SWR grading standards: wettable $(<5 \mathrm{~s})$, slightly water repellent $(5-60 \mathrm{~s})$, strongly water repellent $(60-600 \mathrm{~s})$, severely water repellent $(600-3600 \mathrm{~s})$, extremely water repellent $(>3600 \mathrm{~s})$. The data were differentiated by different environmental factors (such as land use, soil type, soil depth and interference type) and the impacts of different environmental factors on SWR were analyzed. We sorted the data with Microsoft Excel 2010 at first, and did the further description and analysis job with IBM SPSS Statistics21.0, finally drew the charts with Origin8.0. 
Table 1. Land use, location and additional details about data collection

\begin{tabular}{|c|c|c|c|c|}
\hline Category & $\begin{array}{c}\text { Natural ecological } \\
\text { zone* }\end{array}$ & Site & Content & Reference \\
\hline Forests & $\begin{array}{l}\text { Western transitional } \\
\text { tropical, tropical } \\
\text { monsoon rain forest } \\
\text { ecological zone } \\
\text { others }\end{array}$ & \begin{tabular}{|} 
Gaojian forest in Zhuzhou \\
city,Huangfeng bridge \\
forest in Zhuzhou City \\
Youxian County, \\
Zhaoshan demonstration \\
area in Xiangtan city \\
\\
Tropical rainforest \\
ecological station, Chinese \\
Academy of Sciences \\
Xishuangbanna Tropical \\
Botanical Garden \\
Berry, Bitzaron, Magon, \\
Seder Boker
\end{tabular} & \begin{tabular}{|} 
Chinese fir plantation, Pinus \\
massoniana plantation, Pinus \\
massoniana and coniferous and \\
broad-leaved mixed forest; Sassafras \\
fir wood mixed forest; Liquidambar \\
formosana secondary forest; Pinus \\
massoniana mixed forest; Schima \\
superba mixed forest; Pinus \\
massoniana \\
Tropical original seasonal rain \\
forest, artificial rubber forest \\
Economic forest
\end{tabular} & \\
\hline $\begin{array}{c}\text { Grassland \& } \\
\text { Farmland }\end{array}$ & $\begin{array}{l}\text { Warm temperate forest } \\
\text { grassland, clustered } \\
\text { grass grassland } \\
\text { ecological zone } \\
\text { Temperate dwarf semi - } \\
\text { arid desert ecological } \\
\text { zone } \\
\text { Temperate forest } \\
\text { grassland, clustered } \\
\text { grass grassland } \\
\text { ecological zone }\end{array}$ & $\begin{array}{l}\text { Tielongwan forest in } \\
\text { Yichuan County } \\
\text { Manas River Basin in } \\
\text { Xinjiang Uygur } \\
\text { Autonomous Region } \\
\text { Yangcao sample site }\end{array}$ & $\begin{array}{l}\text { Populus davidiana, Artificial Pinus } \\
\text { tabulaeformis, Hippophae } \\
\text { rhamnoides, yellow thorns, pear } \\
\text { seabuckthorn mixed forest, Robinia } \\
\text { pseudoacacia, Agropyron, etc. } \\
\text { Economic forest, no forest land }\end{array}$ & \\
\hline
\end{tabular}

Hou Hsioh-yu, (Chinese vegetation and its geographical distribution) .Ann. Missouri BOT.GARD.1983

Table 2. Soil types and standardizing according to Food and Agriculture Organization (FAO) in China (or Israel)

\begin{tabular}{|c|c|c|}
\hline Category & FAO & Chinese soil \\
\hline Aeolian soils & Arenosols & Aeolian soils \\
\hline Calcisols & Calcisols & \\
\hline Red earths & Ferralic Cambisols; Haplic Alisols & $\begin{array}{c}\text { Torrid red soils; Latosolic red earths; Red earths; Yellow } \\
\text { earths }\end{array}$ \\
\hline Red-yellow earth & $\begin{array}{l}\text { Haplic alisols; haplic acrisols; Ferralic } \\
\text { Cambisols }\end{array}$ & $\begin{array}{l}\text { Latosolic red earths; Red earths; Yellow earths; Latosols; } \\
\text { Torrid red soils }\end{array}$ \\
\hline $\begin{array}{l}\text { Gray-brown } \\
\text { desert soil }\end{array}$ & Haplic Calcisols; Calcaric Fluvisols & $\begin{array}{l}\text { Brown caliche soils; Gray desert soils; Gray-brown } \\
\text { desert soils; Irrigated silting soils; Irrigated desert soils }\end{array}$ \\
\hline $\begin{array}{l}\text { Yellow-brown } \\
\text { earths }\end{array}$ & $\begin{array}{c}\text { Haplic luvisols; albic luvisols; eutric } \\
\text { ambisols; dystric ambisols; ferric luvisols }\end{array}$ & $\begin{array}{l}\text { Yellow-brown earths; Brown earths; Dark-brown earths; } \\
\text { Gray-cinnamon soils; Mountain meadow soils }\end{array}$ \\
\hline $\begin{array}{l}\text { Castano- } \\
\text { cinnamon soils }\end{array}$ & Kastanozems & Castanozems; Castano-cinnamon soils \\
\hline Regosols & Regosols & \\
\hline
\end{tabular}

\section{Data Availability}

All data generated or analysed during this study are included in Supplementary Information files. 


\section{Results}

\section{SWR}

China and Israel soil WDPT was (median) $7 \mathrm{~s}$, from 0.503-4990.84 s (Fig. 2, Table S1). Most soils had water repellency (75.96\%) in which slightly water-repellent soil predominated (58.22\%), followed by no water-repellent soil (close to $24.04 \%$ of the total), strong water repellency and severe water repellency soil added up to $17.49 \%$, and few extremely water-repellent soil (0.26\%) (Fig. 3, Table S2).

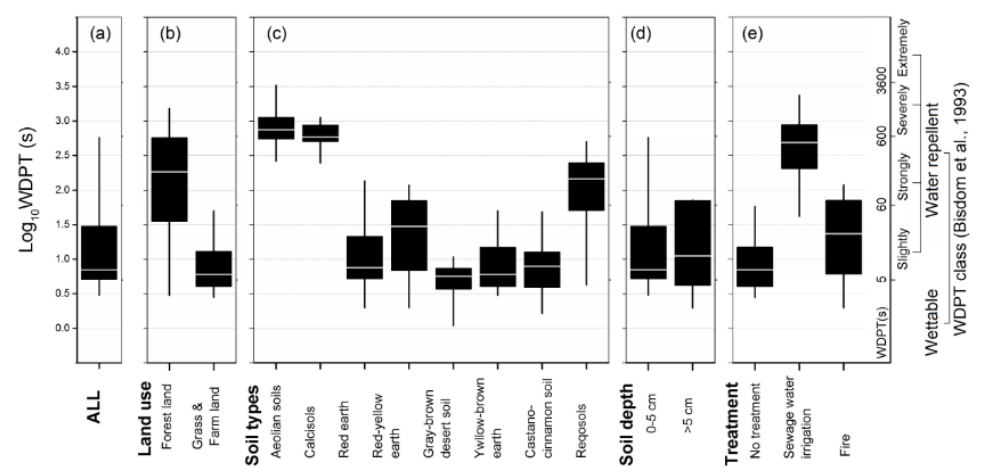

Figure 2. Distribution of soil water repellency characteristics in China and Israel. WDPT data were standardized into $\log _{10}$, SWR was divided into five levels according to WDPT (Bisdom et al., 1993): wettable soil(WDPT<5 s), slightly water repellent(WDPT range 5-60 s), strongly water repellent (WDPT range 60-600 s), severely water repellent (WDPT range 600-3600 s), extremely water repellent (WDPT>3600s). (a)Summary distribution characteristics of SWR;

(b)-(e)SWR distribution along different environmental gradients: (b)land use, (c)soil type,

(d)soil depth, (e)treatment. In the boxplot, the line within the box represents the median, the lower boundary of each box means the first quartile $\left(25^{\text {th }}\right.$ percentile), while the upper boundary is the third quartile ( $75^{\text {th }}$ percentile) of the distribution. The lower the upper error bars are the $1^{\text {st }}$ and $99^{\text {th }}$ percentile value in the distribution, respectively

\section{SWR distribution}

Most Chinese soils were slightly water-repellent, but they showed different SWR differentiation characteristics under different gradients of land use, soil type, soil depth and disturbance type (Fig. 2, Fig. 3).

In different land uses, the forest ecosystem SWR was stronger than grassland and farmland ecosystem SWR. The forest ecosystem soil WDPT ranged from $0.9 \mathrm{~s}$ to $4988.8 \mathrm{~s}$ with nearly half of the soils showed strong water repellency (WDPT median value was $183.831 \mathrm{~s}$ and the strong water repellent soil accounted for $45.77 \%$ ). The non-forest soil WDPT was in the range of $0.5 \mathrm{~s}$ to $350 \mathrm{~s}$ with most soils showed a slight water repellency (WDPT median value was $6 \mathrm{~s}$ and the slightly water-repellent soil accounted for $67.76 \%$ ) (Table S1, Table S2).

The SWR differentiation characteristics of different soil types was significant, especially the Aeolian soils, Calcisols and Regosols (The WDPT median values were 740.876 s, 580.694 s and 144.273 s, respectively). Most Aeolian soils showed severely water repellency $(61.11 \%)$, Calcisols mainly showed strong soil water repellent and severely soil water repellent (55.56\% and $44.44 \%)$, and the Regosols mainly were strong water repellent $(69.44 \%)$. 
The rest soils (Gray-brown desert soil, Yellow-brown earth, Red earth, Castanocinnamon soil, Red-yellow earth) were slightly water-repellent (The WDPT median values were 5.649, 6, 7.534, 7.877, 29.825 s), occupied 58\%, 68.09\%, 66.13\%, 63.64\%, and $42.69 \%$. The cumulative percentage of the slight water repellency were $100 \%$, $95.66 \%, 88.71 \%, 97.73 \%$, and $62.69 \%$. As for the SWR of different soil depth, the overall topsoil $(0-5 \mathrm{~cm})$ WDPT was less than subsoil $(>5 \mathrm{~cm})$ (The WDPT median values were $7 \mathrm{~s}$ and $11.077 \mathrm{~s}$ ), but the topsoil SWR showed a greater variation than subsoil. The subsoil SWR was obviously the strong water repellency, the topsoil sometimes was severely water repellency or even extremely water repellency. The topsoil WDPT ranged from $0.503 \mathrm{~s}$ to $4990.84 \mathrm{~s}$, covering wettable, slightly water repellent, strongly water repellency, severely water repellency and even extremely water repellency (occupied $23.81 \%, 58.98 \%, 12.12 \%, 4.82 \%$, and $0.27 \%$, respectively), mainly showed the slight water repellency (the cumulative percentage was $82.79 \%$ ). The subsoil WDPT ranged from $0.902 \mathrm{~s}$ to $95.266 \mathrm{~s}$ with the wettable and slightly water repellency accounted for $28.92 \%$ and $41.67 \%$, respectively, but the characteristics of severe water repellency were more obvious than the topsoil $(29.41 \%$, the cumulative percentage was $100 \%$ ).

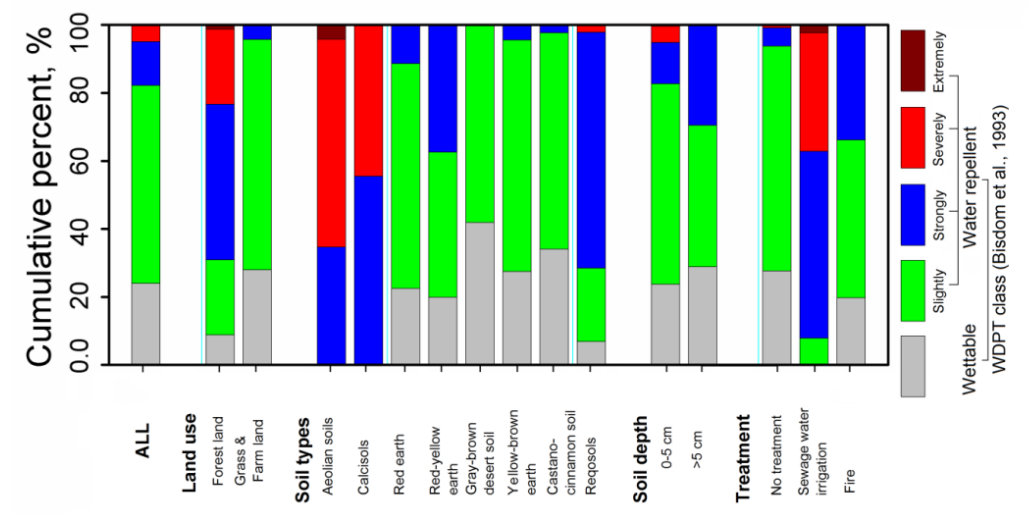

Figure 3. Cumulative percentage distribution of five levels of SWR along different gradients. Gray bars mean wettable soil; green bars represent slight water repellency; blue bars mean strong water repellency; red bars are severe water repellency; while brown bars stand for extreme water repellency

Under different process gradients (no processing, sewage irrigation and fire), no processing soil showed slight soil water repellent (the WDPT median value was $7 \mathrm{~s}$, ranged from $0.503 \mathrm{~s}$ to $1225.211 \mathrm{~s}$, slightly soil water repellent occupied $66.14 \%$, the cumulative percentage was $93.85 \%$ ). Sewage irrigation had the greatest impact on SWR and definitely will cause SWR (wettable soil account for $0 \%$ ). The soil under sewage irrigation (The WDPT median value was $485.584 \mathrm{~s}$, ranged from $6.315 \mathrm{~s}$ to $4990.84 \mathrm{~s}$ ) showed strongly soil water repellency $(54.92 \%$, cumulative percentage of $62.88 \%)$ and severely soil water repellency $(34.85 \%$, cumulative percentage of $97.73 \%$ ) and a few extremely soil water repellency $(2.27 \%)$.

The soil after fire disturbance (the WDPT median value is $23.183 \mathrm{~s}$, ranged from $0.902 \mathrm{~s}$ to $369.766 \mathrm{~s}$ ) might not cause SWR (wettable soil accounted for $19.81 \%$ ), most were slightly water repellent $(46.43 \%)$, and partially strongly water repellency $(33.77 \%)$, without severely water repellency and extremely water repellent soil $(0 \%)$. 


\section{Discussions}

\section{Synthesis}

Existing researches tended to measure SWR at specific sites through a single experiment or long-term monitoring. The choice of sites most depended on the research contents, for example, some researches specifically concentrated in the regions where the distribution of SWR were common and the climate was arid and semi-arid Mediterranean climate areas (e.g. Germany, Spain and California). Some researches chose the humid forest of Central Europe (Buczko et al., 2002; Hubbert and Oriol, 2005; Khanchoul and Boubehziz, 2019). The researches that study the SWR in large scale area were few. China has a vast territory; some regions are humid (South Central) and some are arid and semi-arid regions (West and North). China and Israel faced frequent droughts and the crisis of reclaimed water and available water in recent years (Medina, 2010; Joseph et al., 2019). Most soils in China and Israel showed SWR, mainly were slightly water repellent and contained different degrees (the range of WDPT were $0.503 \mathrm{~s}-4990.84 \mathrm{~s}$ ). For example, it could be seen from the SWR reports about the Mediterranean climate region (semi-arid zone) that some researchers suggested that the soils were slightly water-repellent with the WDPT ranged from $10 \mathrm{~s}$ to $30 \mathrm{~s}$ (Mataix-Solera et al., 2007), and some other researchers found that the forest soil in the Mediterranean climate region was strong water repellency and even extremely water repellency (Crockford et al., 1991; Wahl, 2008; Oyedotun, 2018). In this study, we sampled all SWR researches which could represent the SWR in China.

\section{Characterization}

Soil as a giant container and complicate system, it currently focuses on the causes of SWR (such as fire or hydrophobic organic matter) (Jiménez-Pinilla et al., 2016; Siteur et al., 2016), predicts and simulates the emergence of SWR through some leading factors, such as land type, litter type, soil properties, operation mode, microbe activity, seasonal variation, etc. (Buczko et al., 2007; Schmitt et al., 2010; Jordán et al., 2013; Cesarano et al., 2016), and compares and improves the research methods (Doerr, 1998; Wahl, 2008; Sharma and Yadav, 2018). But the previous researches were always just a single experiment report, no one described SWR integratedly and from different gradients. In this study, the SWR distribution situation and distribution pattern were described from four perspectives: land use, soil type, soil depth and interference type.

There were more comparative studies about the impact of land use on SWR than others. Previous studies suggested that the bare land or wilderness would show extreme water repellency, while the soils under vegetation showed less significant, SWR could be limited by vegetation cover type and availability of litter (Arcenegui et al., 2007; Zavala et al., 2009). The influence of different vegetation cover types on SWR had great different, this result was same as our research. It universally accepted that grass and farmland which were generally wettable soil and slightly water-repellent soil showed less severity water repellency than forest that usually showed strong water repellency as well as severe water repellency and even some serious water repellency (Mataix-Solera et al., 2007; Buczko et al., 2007; Verheijen and Cammeraat, 2007; Kořenková et al., 2015; Walden et al., 2015). Human disturbance, such as different farming methods did not seem to be the cause of these differences (Malvar et al., 2016), different soil organic contents (SOC) of different land types might be the reason. There was a significant positive correlation between SOC and SWR $(\mathrm{r} 2=0 \bullet 74, \mathrm{p}=0 \bullet 01)$, and the soil with SOC 
content higher than $8.06 \%$ might have SWR. There were different views in some researches. By comparing three different land uses (eucalyptus, grassland and shrub) in Australia, it was found that the diversity of SWR was independent of soil properties such as SOC content and composition, that might be caused by inducing a small amount of hydrophobic compounds from the trees. However, eucalyptus seemed to be a significant tree species in terms of SWR. Compared with other species, the eucalyptus SWR had a greater variation range and a more complex dynamic change process (Rodríguez-Alleres and Benito, 2011; Santos et al., 2013). And SWR might vary according to different forest types, for example, pure forest exhibited relatively low SWR when compared with mixed forest (Buczko et al., 2002, 2005). Deciduous broadleaved forest showed a higher SWR when compared to coniferous forest (Gimbel et al., 2016). Some studies assumed that SWR might be irrelevant to forest types (Wahl, 2008). However, they suggested that the diversity in humus brought about different levels of SWR. For example, the humus species of mixed and deciduous broad-leaved forests were more complex and the surface soil humus was thicker than pure forest and coniferous forest (Buczko et al., 2002, 2005; Wahl et al., 2005). On the other hand, the higher SWR may be accompanied by the humus form of "ecologically less favorable" (e.g. moder and mor-like forms) (Sevink et al., 1989; Scott and Wyk, 1990; Crockford et al., 1991; Imeson et al., 1992).

Different soil types played an important role in SWR diversity, and the SWR might be the loopholes in soil system operation. Therefore, it was overgeneralization to study and explain the causes of SWR and predict the variation trend only from the individual soil properties. This study described the SWR distribution patterns of 8 different soil types (Aeolian soils, Calcisols, Regosols, Red earth, Red-yellow earth, Yellow-brown earth, Gray-brown desert soil, Castano-cinnamon soil) that were common in China and Israel. Aeolian soils and Calcisols, the two most serious water-repellent soil types were typical sandy soils with poor water holding capacity and widely distributed in arid and semi-arid areas (Zhenghu et al., 2007; Chesworth et al., 2008). Regosols which considered to be "taxonomic rest group" exhibited serious SWR, its particle size was between sand and clay (Meek et al., 2008). Other soil types were slightly water repellent and some strongly water repellent. Among them, Red earth (Alisols), Red-yellow earth (Acrisols), Yellow-brown earth (luvisols) belonged to mafic soils, the difference between them were the different properties and the development of the parent rock and the initial rock (Lal and Stewart, 2011), higher clay content, stronger acidity and the water holding capacity, limited agricultural use. They were usually forested areas and some low intensity pasture (Yu, 1997; Ebelhar et al., 2008; Dahlgren et al., 2008). Graybrown desert soil was a typical Fluvisols that was adaptable for xerophytes. It usually possessed the features of sedimentary soils in lakes and seas that might exhibit low $\mathrm{pH}$, high aluminum and salt content (Paz et al., 2008). Castano-cinnamon soil with relatively high humus content was a typical grassland soil (Spaargaren, 2008). The study on integrated report of different soil types had been done little so far, and the existing studies usually was a small sample (dozens of samples), small scale (covers few soil types), focusing on the nature of soil as well as trying to explain and forecast the SWR from a single perspective, and so on. The few existing studies made a comparison among several particular soil types, such as Regosol in the semi-arid regions of the Mediterranean was more prone to SWR than Luvisol (Arcenegui et al., 2007). Cambisols and Podsols in broad-leaved and coniferous forests in northern Europe (Jutland and Denmark) were strong water-repellent soil (Wahl, 2008). Most Cambreeol 
and Leptosol in the European mountains were slightly water-repellent soils and little parts were strongly water-repellent soil, Luvisol and Regosols were slightly waterrepellent and strongly water-repellent soil, Fluvisols were slightly water-repellent soil (Kořenková et al., 2015). Most of the studies focused on the influence of different soil properties on SWR, and tried to explain the differences of SWR in different soil types (Mirbabaei et al., 2013). The focused soil properties were concentrated on the soil texture, SOC, pH, moisture content, the role of clay particle, soil elements content, etc., but there were different opinions about the dominant factor. In this study, Aeolian soils, Calcisols and Regosols from arid and semi-arid areas had a higher sediment concentration, the clay content was lower and water repellent was most significant comparing with the remaining five soils. It had been widely believed that soils from forest or farmland systems which were rich in sediment concentration were more likely to exhibit SWR. SWR might be positively correlated with sediment concentration, and there was a negative correlation with clay content, but the magnitude of correlation was still controversial (Mirbabaei et al., 2013; Kořenková et al., 2015). However, there were reports that SWR (South Africa) negatively correlated with sediment concentration (Scott, 2000), and different amounts of sediment in the same soil type were not significantly associated with SWR (Dekker and Ritsema, 1994; Wahl, 2008) and so on. Similar to the reports of different land uses, SOC was also considered to be the cause of SWR differences in different soil uses. Mafic soils which widely distributed in the south-central part of China had a large amount of cosmid content, low SOC and $\mathrm{pH}$ content and showed slightly water repellent. The previous studies concluded that SOC content positively correlated with SWR (Buczko et al., 2002; Mirbabaei et al., 2013; Kořenková et al., 2015), however, it also been suggested that SOC was not the main cause of SWR (Wahl, 2008; Vogelmann et al., 2010), pH which negatively correlated with SWR was the dominant property of SWR differences, and we could alleviate SWR by increasing the soil pH (Ritsema et al., 1998; Hurraß and Schaumann, 2006; MataixSolera et al., 2007; Mirbabaei et al., 2013; Kořenková et al., 2015).

Most of the SWR research would first assume that the soil humus had a huge impact and effect, their research often focused on topsoil $(0-5 \mathrm{~cm}$ ) (Santos et al., 2013; Bachmann et al., 2016; Robichaud et al., 2016). However, most of these studies drew conclusions from a single experiment, it often could not verify all SWR changes in topsoil and subsoil $(>5 \mathrm{~cm})$ by this single experiment. SWR occurred mainly in topsoil which was more prone to produce strong or stronger water repellency than subsoil according to previous studies (Reeder and Jurgensen, 1979; Wahl, 2008; Robichaud et al., 2016). By analyzing the SWR distribution pattern along different depths in different areas, vegetation cover types and soil types, it had been found that topsoil had a great SWR variation, covering strongly water repellency, severely water repellency and extremely water repellency $(17.21 \%)$, but the median value of WDPT was less than subsoil, and although subsoil didn't show severely water repellency and extremely water repellency, the probability of SWR was greater than topsoil (29.4\%). Therefore, it might be incomplete that most studies had found SWR might decrease with increasing soil depth (Barrett and Slaymaker, 1989; Doerr et al., 2000; Walden et al., 2015; Malvar et al., 2016), the gradient variation and trend of SWR along different soil layer depth might be more complicated than the existing researches.

Many studies suggested that fire interference was the main reason of SWR and would exacerbate SWR (Reeder and Jurgensen, 1979; DeBano, 2000; Doerr et al., 2000; Jordán et al., 2013; Jiménez-Pinilla et al., 2016). More than $40 \%$ of SWR was due to 
fire disturbance (Reeder and Jurgensen, 1979), hence a large number of experiments designed with different fire intensities to measure the forest soil SWR, investigate the response of forest types, structures, soil infiltration capacity and runoff rate after fire disturbance (Robichaud et al., 2016), so as to guide forest management, forest soil protection and restoration, forest reconstruction after fire, etc. However, it had found that the fire did not always lead to SWR by integrating the fire interference experiments data, appropriate small fire might not affect SWR (wettable soil 27.71\%), the maximum WDPT caused by fire even less than the WDPT of no interference soil (369.766 and $1225.211 \mathrm{~s}$ ). In contrast to fire, sewage irrigation might be a more serious problem for SWR, especially in China and Israel where droughts, reclaimed water and available water crises occurred frequently (Medina, 2010). Irrigation with sewage would be common in the future, especially in arid and semi-arid areas where available water was short. Unlike fire interference, sewage irrigation would certainly cause SWR (wettable soil $0 \%$ ), and far more serious. This might be related to the ingredients of sewage. It had been found that diluted soapy water could accelerate the wetting rate of the water repellent soil at the beginning, but when the moisture was slowly lost, the soil that added the surfactant showed even more severe water repellency than before (Jamison, 1943). Various cationic, anionic, non-ionic substances could humidify soil faster (Cisar et al., 2000), but the surface-active substances would increase soil hydrophobicity after being wet (Adhikari and Chakrabarti, 1976). In addition, sewage irrigation also increased the biological activity and abundance of soil organisms (Barkle et al., 2000), which might also be responsible for increasing SWR (Bond and Harris, 1964).

\section{Summary and Conclusions}

Through full sampling analysis of SWR in China and Israel, it had found that SWR were widespread in China, but most were only slightly water-repellent. Only a small part of the soil had strong water repellency or stronger water repellency. The main factors affecting SWR were soil type, soil depth, land use, type of disturbance, etc. There was a significant difference in SWR between different soil types, due to different soil properties. The order of SWR is Aeolian soils $>$ Calcisols $>$ Regosols $>$ Red-yellow earth $>$ Red earth $>$ Yellow-brown earth $>$ Castano-cinnamon soil $>$ Gray-brown desert soil. SWR tended to decrease with the increase of soil depth, and the external disturbance had a great influence on the water repellency of topsoil, and had little effect on subsoil. There was a significant difference in SWR between different land use, and there was a significant SWR in forest ecosystems compared with grassland and farmland. A certain intensity of fire interference and sewage irrigation would exacerbate the water repellent in the soil, in which the impact of sewage irrigation on SWR was more significant, the SWR would increase with the increase of fire intensity. The reasons for different SWR will be worth studying in the future. The results of this study filled the gaps in the evaluation of the overall water repellency of soils in China and Israel, and summarized the factors affecting SWR, which would provide the basis for soil improvement and ecological restoration in China and even the world.

Acknowledgements. This study was financially supported by the National Natural Science Foundation of China (No. 31470659), the forestry public industry scientific research project (No: 201504301). 


\section{REFERENCES}

[1] Adhikari, M., Chakrabarti, G. (1976): Contribution of natural and microbial humic acids to water repellency in soil. - Journal of the Indian Society of Soil Science: 217-219.

[2] Ali, W., Nasir, M. S., Nasir, A., Rashid, H., Ayub, I., Gillani, S. H., Latif, M. J. (2018): Assessment Of Carbon Footprints In Terms Of Co2 Of Diesel Generator, Pakistan. - Earth Sciences Pakistan 2(1): 15-17.

[3] Arcenegui, V., Mataix-Solera, J., Guerrero, C., Zornoza, R., Mayoral, A. M., Morales, J. (2007): Factors controlling the water repellency induced by fire in calcareous Mediterranean forest soils. - European Journal of Soil Science 58: 1254-1259.

[4] Bachmann, J., Krueger, J., Goebel, M. O., Heinze, S. (2016): Occurrence and spatial pattern of water repellency in a beech forest subsoil. - Journal of Hydrology and Hydromechanics 64: 100-110.

[5] Barkle, G. F., Stenger, R., Singleton, P. L., Painter, D. J. (2000): Effect of regular irrigation with dairy farm effluent on soil organic matter and soil microbial biomass. - Australian Journal of Soil Research 38: 1087-1097.

[6] Barrett, G., Slaymaker, O. (1989): Identification, characterization, and hydrological implications of water repellency in mountain soils, southern British Columbia. - Catena 16: 477-489.

[7] Bisdom, E. B. A., Dekker, L. W., Schoute, J. F. Th. (1993): Water repellency of sieve fractions from sandy soils and relationships with organic material and soil structure. Geoderma 56: 105-118.

[8] Bogner, C., Wolf, B., Schlather, M., Huwe, B. (2008): Analysing flow patterns from dye tracer experiments in a forest soil using extreme value statistics. - European Journal of Soil Science 59: 103-113.

[9] Bond, R., Harris, J. (1964): The influence of the microflora on the physical properties of soils. I. Effects associated with filamentous algae and fungi. - Australian Journal of Soil Research 2: $111-122$.

[10] Buczko, U., Bens, O., Fischer, H., Hüttl, R. F. (2002): Water repellency in sandy luvisols under different forest transformation stages in northeast Germany. - Geoderma 109: 1-18.

[11] Buczko, U., Bens, O., Hüttl, R. F. (2005): Variability of soil water repellency in sandy forest soils with different stand structure under Scots pine (Pinus sylvestris) and beech (Fagus sylvatica). - Geoderma 126: 317-336.

[12] Buczko, U., Bens, O., Hüttl, R. F. (2007): Changes in soil water repellency in a pine-beech forest transformation chronosequence: Influence of antecedent rainfall and air temperatures. Ecological Engineering 31: 154-164.

[13] Butzen, V., Seeger, M., Marruedo, A., de Jonge, L., Wengel, R., Ries, J. B., Casper, M. C. (2015): Water repellency under coniferous and deciduous forest - Experimental assessment and impact on overland flow. - Catena 133: 255-265.

[14] Cesarano, G., Incerti, G., Bonanomi, G. (2016): The Influence of Plant Litter on Soil Water Repellency: Insight from 13C NMR Spectroscopy. - PloS one 11: e0152565.

[15] Chesworth, W., Camps Arbestain, M., Macías, F., Spaargaren, O. (2008): Calcisols. - In: Chesworth, W. (ed.) Encyclopedia of Soil Science. Springer Netherlands: 79-80.

[16] Cisar, J. L., Williams, K. E., Vivas, H. E., Haydu, J. J. (2000): The occurrence and alleviation by surfactants of soil-water repellency on sand-based turfgrass systems. - Journal of Hydrology 231-232: 352-358.

[17] Craswell, E. T., Lefroy, R. D. B. (2001): The role and function of organic matter in tropical soils. - Nutrient Cycling in Agroecosystems 61: 7-18.

[18] Crockford, H., Topalidis, S., Richardson, D. (1991): Water repellency in a dry sclerophyll eucalypt forest - measurements and processes. - Hydrological Processes 5: 405-420.

[19] Dahlgren, R. A. (2008): Acrisols. - In: Chesworth, W. (ed.) Encyclopedia of Soil Science. Springer Netherlands: 22-24. 
[20] DeBano, L. F. (2000): Water repellency in soils: a historical overview. - Journal of Hydrology 231-232: 4-32.

[21] DeBano, L. F. (2000): The role of fire and soil heating on water repellency in wildland environments: a review. - Journal of Hydrology and Hydromechanics 231-232: 195-206.

[22] Dekker, L. W., Ritsema, C. J. (1994): How water moves in a water repellent sandy soil: 1. Potential and actual water repellency. - Water Resources Research 30: 2507-2517.

[23] Doerr, S. H. (1998): On standardizing the 'Water Drop Penetration Time' and the 'Molarity of an Ethanol Droplet' techniques to classify soil hydrophobicity: A case study using medium textured soils. - Earth Surface Processes and Landforms 23: 663-668.

[24] Doerr, S. H., Shakesby, R. A., Walsh, R. P. D. (2000): Soil water repellency: its causes, characteristics and hydro-geomorphological significance. - Earth-Science Reviews 51: 33-65.

[25] Ebelhar, S. A., Chesworth, W., Paris, Q., Spaargaren, O. (2008): Luvisols. - In: Chesworth, W. (ed.) Encyclopedia of Soil Science. Springer Netherlands: 440-442.

[26] Fang, N. F., Wang, L., Shi, Z. H. (2017): Runoff and soil erosion of field plots in a subtropical mountainous region of China. - Journal of Hydrology 552: 387-395.

[27] Gimbel, K. F., Puhlmann, H., Weiler, M. (2016): Does drought alter hydrological functions in forest soils? - Hydrology and Earth System Sciences 20: 1301-1317.

[28] Hossain, M. S., Karlson, M., Neset, T. S. (2019): Application Of Gis For Cyclone Vulnerability Analysis Of Bangladesh. - Earth Sciences Malaysia 3(1): 25-34.

[29] Hubbert, K. R., Oriol, V. (2005): Temporal fluctuations in soil water repellency following wildfire in chaparral steeplands, southern California. - International Journal of Wildland Fire 14: 439-447.

[30] Hurraß, J., Schaumann, G. E. (2006): Properties of soil organic matter and aqueous extracts of actually water repellent and wettable soil samples. - Geoderma 132: 222-239.

[31] Imeson, Dr. A. C., Verstraten, Dr. J. M., van Mulligen, Dr. E. J., Sevink, Dr. J. (1992): The effects of fire and water repellency on infiltration and runoff under Mediterranean type forest. - Catena 19: 345-361.

[32] Jamison, V. C. (1943): The slow reversible drying of sandy surface soils beneath citrus trees in central Florida. - Soil Science Society of America Journal 7: 36-41.

[33] Jiménez-Pinilla, P., Doerr, S. H., Ahn, S., Lozano, E., Mataix-Solera, J., Jordán, A., Zavala, L. M., Arcenegui, V. (2016): Effects of relative humidity on the water repellency of fireaffected soils. - Catena 138: 68-76.

[34] Jordán, A., Zavala, L. M., Mataix-Solera, J., Doerr, S. H. (2013): Soil water repellency: Origin, assessment and geomorphological consequences. - Catena 108: 1-5.

[35] Joseph, O. T., Adeoti, O. O., Olufemi, A. A. (2019): Study Of The Phytodiversity Along Antorun Reservoir, Near Ogbomoso, Nigeria. - Environment \& Ecosystem Science 3(1): 112 .

[36] Khanchoul, K., Boubehziz, S. (2019): Spatial Variability Of Soil Erodibility At El Hammam Catchment, Northeast Of Algeria. - Environment \& Ecosystem Science 3(1): 17-25.

[37] Kořenková, L., Šimkovic, I., Dlapa, P., Juráni, B., Matúš, P. (2015): Identifying the origin of soil water repellency at regional level using multiple soil characteristics: The White Carpathians and Myjavska pahorkatina Upland case study. - Soil and Water Research 10: 7889.

[38] Lal, R., Stewart, B. A. (2011): World soil resources and food security. - CRC Press.

[39] Liang, Z., Wenshun, W. (2019): Parametric Architectural Design Based On Optimization Algorithm. - Engineering Heritage Journal 3(1): 13-17.

[40] Malvar, M. C., Prats, S. A., Nunes, J. P., Keizer, J. J. (2016): Soil Water Repellency Severity and its Spatio-Temporal Variation in Burnt Eucalypt Plantations in North-Central Portugal. Land Degradation \& Development 27: 1463-1478.

[41] Mataix-Solera, J., Arcenegui, V., Guerrero, C., Mayoral, A. M., Morales, J., González, J., García-Orenes, F., Gómez, I. (2007): Water repellency under different plant species in a calcareous forest soil in a semiarid Mediterranean environment. - Hydrological Processes 21: 2300-2309. 
[42] Medina, M. A. (2010): Global Water Crisis and Climate Change. - Journal of Hydrologic Engineering 15: 167-170.

[43] Meek, B. D., Chesworth, W., Spaargaren, O. (2008): Regosols. - In: Chesworth, W. (ed.) Encyclopedia of Soil Science. Springer Netherlands: 605-606.

[44] Mirbabaei, S. M., Shahrestani, M. S., Zolfaghari, A., Abkenar, K. T. (2013): Relationship between soil water repellency and some of soil properties in northern Iran. - Catena 108: 2634.

[45] Oyedotun, T. D. T. (2018): X-ray fluorescence (XRF) in the investigation of the composition of earth materials: a review and an overview. - Geology, Ecology, and Landscapes 2(2): 138154.

[46] Paz, C. G. (2008): Fluvisols. - In: Chesworth, W. (ed.) Encyclopedia of Soil Science. Springer Netherlands: 281-282.

[47] Reeder, C. J., Jurgensen, M. F. (1979): Fire-induced water repellency in forest soils of upper Michigan. - Canadian Journal of Forest Research 9: 369-373.

[48] Ritsema, C. J., Dekker, L. W., Nieber, J. L., Steenhuis, T. S. (1998): Modeling and field evidence of finger formation and finger recurrence in a water repellent sandy soil. - Water Resources Research 34: 555-567.

[49] Robichaud, P. R., Wagenbrenner, J. W., Pierson, F. B., Spaeth, K. E., Ashmun, L. E., Moffet, C. A. (2016): Infiltration and interrill erosion rates after a wildfire in western Montana, USA. - Catena 142: 77-88.

[50] Rodríguez-Alleres, M., Benito, E. (2011): Spatial and temporal variability of surface water repellency in sandy loam soils of NW Spain under Pinus pinaster and Eucalyptus globulus plantations. - Hydrological Processes 25: 3649-3658.

[51] Santos, J. M., Verheijen, F. G. A., Tavares Wahren, F., Wahren, A., Feger, K.-H., BernardJannin, L., Rial-Rivas, M. E., Keizer, J. J., Nunes, J. P. (2013): Soil Water Repellency Dynamics in Pine and Eucalypt Plantations in Portugal - A High-resolution Time Series. Land Degradation \& Development 27: 1334-1343.

[52] Sblackwell, P. (2000): Management of water repellency in Australia, and risks associated with preferential flow, pesticide concentration and leaching. - Journal of Hydrology 231-232: 384-395.

[53] Schmitt, A., Glaser, B., Borken, W., Matzner, E. (2010): Organic matter quality of a forest soil subjected to repeated drying and different re-wetting intensities. - European Journal of Soil Science 61: 243-254.

[54] Scott, D. F., Wyk, D. B. V. (1990): The effects of wildfire on soil wettability and hydrological behaviour of an afforested catchment. - Journal of Hydrology 121: 239-256.

[55] Scott, D. (2000): Soil wettability in forested catchments in South Africa; as measured by different methods and as affected by vegetation cover and soil characteristics. - Journal of Hydrology 231: 87-104.

[56] Sevink, J., Imeson, A. C., Verstraten, J. M. (1989): Humus form development and hillslope runoff, and the effects of fire and management, under Mediterranean forest in NE-Spain. Catena 16: 461-475.

[57] Sharjeel, A., Anwar, S., Nasir, A., Rashid, H. (2019): Design, Development And Performance Of Optimum Water Softener. - Earth Sciences Pakistan 3(1): 23-28.

[58] Sharma, D., Yadav, K. D. (2018): Application of rotary in-vessel composting and analytical hierarchy process for the selection of a suitable combination of flower waste. - Geology, Ecology, and Landscapes 2(2): 137-147.

[59] Siteur, K., Mao, J., Nierop, K. G. J., Rietkerk, M., Dekker, S. C., Eppinga, M. B. (2016): Soil Water Repellency: A Potential Driver of Vegetation Dynamics in Coastal Dunes. Ecosystems 19: 1210-1224.

[60] Spaargaren, O. (2008): Kastanozems. - In: Chesworth, W. (ed.) Encyclopedia of Soil Science. Springer Netherlands: 421-423. 
[61] Sunny, A. A., Omowumi, A., Chris, O. A. (2018): Improved Magnetic Data Analyses And Enhancement Techniques For Lithological And Structural Mapping Around Akure, Southwestern Nigeria. - Earth Sciences Malaysia 2(1): 16-21.

[62] Tao, S. (2018): Evaluation Of Technology Innovation In Hubei Province. - Engineering Heritage Journal 2(2): 09-10.

[63] Verheijen, F. G. A., Cammeraat, L. H. (2007): The association between three dominant shrub species and water repellent soils along a range of soil moisture contents in semi-arid Spain. Hydrological Processes 21: 2310-2316.

[64] Vogelmann, E. S., Reichert, J. M., Reinert, D. J., Mentges, M. I., Vieira, D. A., de Barros, C. A. P., Fasinmirin, J. T. (2010): Water repellency in soils of humid subtropical climate of Rio Grande do Sul, Brazil. - Soil and Tillage Research 110: 126-133.

[65] Wahl, N. A., Wöllecke, B., Bens, O., Hüttl, R. (2005): Can forest transformation help reducing floods in forested watersheds? Certain aspects on soil hydraulics and organic matter properties. - Physics and Chemistry of the Earth, Parts A/B/C 30: 611-621.

[66] Wahl, N. A. (2008): Variability of Water Repellency in Sandy Forest Soils under Broadleaves and Conifers in north-western Jutland/Denmark. - Soil and Water Research 3: S155-S164.

[67] Walden, L. L., Harper, R. J., Mendham, D. S., Henry, D. J., Fontaine, J. B. (2015): Eucalyptus reforestation induces soil water repellency. - Soil Research 53: 168-177.

[68] Yu, T. R. (1997): Chemistry of Variable Charge Soils. - Oxford University Press.

[69] Zavala, L. M., González, F. A., Jordán, A. (2009): Intensity and persistence of water repellency in relation to vegetation types and soil parameters in Mediterranean SW Spain. Geoderma 152: 361-374.

[70] Zhenghu, D., Honglang, X., Zhibao, D., Gang, W., Drake, S. (2007): Morphological, physical and chemical properties of aeolian sandy soils in northern China. - Journal of Arid Environments 68: 66-76.

\section{APPENDIX}

\section{SUPPORTING INFORMATION}

Table S1. Statistical analysis of Log10WDPT along different gradients

\begin{tabular}{|c|c|c|c|c|c|c|c|c|}
\hline & & $\mathbf{N}$ & Median & Mean & SD & SE for Mean & Min. & Max. \\
\hline All & & 4643 & 0.845 & 1.152 & 0.717 & 0.011 & -0.298 & 3.698 \\
\hline \multirow{2}{*}{$\begin{array}{l}\text { Vegetation } \\
\text { Class }\end{array}$} & Forest land & 970 & 2.264 & 2.086 & 0.844 & 0.027 & -0.045 & 3.698 \\
\hline & Grass \& Farm land & 3673 & 0.778 & 0.905 & 0.413 & 0.007 & -0.298 & 2.544 \\
\hline \multirow{8}{*}{ Soil type } & Aeolian soils & 288 & 2.870 & 2.911 & 0.311 & 0.018 & 2.281 & 3.698 \\
\hline & Calcisols & 72 & 2.764 & 2.771 & 0.188 & 0.022 & 2.315 & 3.083 \\
\hline & Red earth & 62 & 0.877 & 1.039 & 0.528 & 0.067 & 0.198 & 2.557 \\
\hline & Red-yellow earth & 260 & 1.475 & 1.335 & 0.609 & 0.038 & -0.045 & 2.568 \\
\hline & Gray-brown desert soil & 100 & 0.752 & 0.664 & 0.298 & 0.030 & -0.298 & 1.150 \\
\hline & Yellow-brown earth & 3529 & 0.778 & 0.912 & 0.414 & 0.007 & 0.000 & 2.544 \\
\hline & Castano-cinnamon soil & 44 & 0.896 & 0.895 & 0.406 & 0.061 & 0.000 & 1.791 \\
\hline & Regosols & 288 & 2.159 & 1.992 & 0.592 & 0.035 & 0.097 & 2.867 \\
\hline \multirow{2}{*}{ Soil depth } & $0-5 \mathrm{~cm}$ & 4439 & 0.845 & 1.153 & 0.722 & 0.011 & -0.298 & 3.698 \\
\hline & $>5 \mathrm{~cm}$ & 204 & 1.044 & 1.128 & 0.590 & 0.041 & -0.045 & 1.979 \\
\hline \multirow{3}{*}{$\begin{array}{c}\text { Disturbance } \\
\text { Class }\end{array}$} & No treatment & 3807 & 0.845 & 0.940 & 0.478 & 0.008 & -0.298 & 3.088 \\
\hline & $\begin{array}{l}\text { Sewage water } \\
\text { irrigation }\end{array}$ & 528 & 2.686 & 2.590 & 0.509 & 0.022 & 0.800 & 3.698 \\
\hline & Fire & 308 & 1.365 & 1.306 & 0.603 & 0.034 & -0.045 & 2.568 \\
\hline
\end{tabular}


Table S2. Percentage and cumulative percentage of five WDPT classes ((Bisdom et al., 1993)

\begin{tabular}{|c|c|c|c|c|c|c|c|c|}
\hline & & & \multirow[b]{2}{*}{ Total } & \multicolumn{5}{|c|}{ WDPT Class } \\
\hline & & & & Wettable & Slightly & Strongly & Severely & Extremely \\
\hline \multirow{3}{*}{ ALL } & & $\mathrm{N}$ & 4643 & 1116 & 2703 & 598 & 214 & 12 \\
\hline & & $\%$ & & 24.04 & 58.22 & 12.88 & 4.61 & 0.26 \\
\hline & & Cumulative $\%$ & & 24.04 & 82.25 & 95.13 & 99.74 & 100.00 \\
\hline \multirow{6}{*}{$\begin{array}{l}\text { Vegetation } \\
\text { Class }\end{array}$} & \multirow{3}{*}{ Forest land } & $\mathrm{N}$ & 970 & 86 & 214 & 444 & 214 & 12 \\
\hline & & $\%$ & & 8.87 & 22.06 & 45.77 & 22.06 & 1.24 \\
\hline & & Cumulative $\%$ & & 8.87 & 30.93 & 76.70 & 98.76 & 100.00 \\
\hline & \multirow{3}{*}{ Grass \& Farm land } & $\mathrm{N}$ & 3673 & 1030 & 2489 & 154 & & \\
\hline & & $\%$ & & 28.04 & 67.76 & 4.19 & 0.00 & 0.00 \\
\hline & & Cumulative $\%$ & & 28.04 & 95.81 & 100.00 & 100.00 & 100.00 \\
\hline \multirow{24}{*}{ Soil type } & \multirow{3}{*}{ Aeolian soils } & $\mathrm{N}$ & 288 & & & 100 & 176 & 12 \\
\hline & & $\%$ & & 0.00 & 0.00 & 34.72 & 61.11 & 4.17 \\
\hline & & Cumulative $\%$ & & 0.00 & 0.00 & 34.72 & 95.83 & 100.00 \\
\hline & \multirow{3}{*}{ Calcisols } & $\mathrm{N}$ & 72 & & & 40 & 32 & \\
\hline & & $\%$ & & 0.00 & 0.00 & 55.56 & 44.44 & 0.00 \\
\hline & & Cumulative $\%$ & & 0.00 & 0.00 & 55.56 & 100.00 & 100.00 \\
\hline & \multirow{3}{*}{ Red earth } & $\mathrm{N}$ & 62 & 14 & 41 & 7 & & \\
\hline & & $\%$ & & 22.58 & 66.13 & 11.29 & 0.00 & 0.00 \\
\hline & & Cumulative $\%$ & & 22.58 & 88.71 & 100.00 & 100.00 & 100.00 \\
\hline & \multirow{3}{*}{ Red-yellow earth } & $\mathrm{N}$ & 260 & 52 & 111 & 97 & & \\
\hline & & $\%$ & & 20.00 & 42.69 & 37.31 & 0.00 & 0.00 \\
\hline & & Cumulative $\%$ & & 20.00 & 62.69 & 100.00 & 100.00 & 100.00 \\
\hline & \multirow{3}{*}{$\begin{array}{l}\text { Gray-brown desert } \\
\text { soil }\end{array}$} & $\mathrm{N}$ & 100 & 42 & 58 & & & \\
\hline & & $\%$ & & 42.00 & 58.00 & 0.00 & 0.00 & 0.00 \\
\hline & & Cumulative $\%$ & & 42.00 & 100.00 & 100.00 & 100.00 & 100.00 \\
\hline & \multirow{3}{*}{$\begin{array}{l}\text { Yellow-brown } \\
\text { earth }\end{array}$} & $\mathrm{N}$ & 3529 & 973 & 2403 & 153 & & \\
\hline & & $\%$ & & 27.57 & 68.09 & 4.34 & 0.00 & 0.00 \\
\hline & & Cumulative\% & & 27.57 & 95.66 & 100.00 & 100.00 & 100.00 \\
\hline & \multirow{3}{*}{$\begin{array}{c}\text { Castano-cinnamon } \\
\text { soil }\end{array}$} & $\mathrm{N}$ & 44 & 15 & 28 & 1 & & \\
\hline & & $\%$ & & 34.09 & 63.64 & 2.27 & 0.00 & 0.00 \\
\hline & & Cumulative\% & & 34.09 & 97.73 & 100.00 & 100.00 & 100.00 \\
\hline & \multirow{3}{*}{ Regosols } & $\mathrm{N}$ & 288 & 20 & 62 & 200 & 6 & \\
\hline & & $\%$ & & 6.94 & 21.53 & 69.44 & 2.08 & 0.00 \\
\hline & & Cumulative\% & & 6.94 & 28.47 & 97.92 & 100.00 & 100.00 \\
\hline \multirow{6}{*}{ Soil depth } & \multirow{3}{*}{$0-5 \mathrm{~cm}$} & $\mathrm{~N}$ & 4439 & 1057 & 2618 & 538 & 214 & 12 \\
\hline & & $\%$ & & 23.81 & 58.98 & 12.12 & 4.82 & 0.27 \\
\hline & & Cumulative\% & & 23.81 & 82.79 & 94.91 & 99.73 & 100.00 \\
\hline & \multirow{3}{*}{$>5 \mathrm{~cm}$} & $\mathrm{~N}$ & 204 & 59 & 85 & 60 & & \\
\hline & & $\%$ & & 28.92 & 41.67 & 29.41 & 0.00 & 0.00 \\
\hline & & Cumulative $\%$ & & 28.92 & 70.59 & 100.00 & 100.00 & 100.00 \\
\hline \multirow{9}{*}{$\begin{array}{l}\text { Disturbance } \\
\text { Class }\end{array}$} & \multirow{3}{*}{ No treatment } & $\mathrm{N}$ & 3807 & 1055 & 2518 & 204 & 30 & \\
\hline & & $\%$ & & 27.71 & 66.14 & 5.36 & 0.79 & 0.00 \\
\hline & & Cumulative $\%$ & & 27.71 & 93.85 & 99.21 & 100.00 & 100.00 \\
\hline & & $\mathrm{N}$ & 528 & & 42 & 290 & 184 & 12 \\
\hline & Sewage water & $\%$ & & 0.00 & 7.95 & 54.92 & 34.85 & 2.27 \\
\hline & & Cumulative\% & & 0.00 & 7.95 & 62.88 & 97.73 & 100.00 \\
\hline & & $\mathrm{N}$ & 308 & 61 & 143 & 104 & & \\
\hline & Fire & $\%$ & & 19.81 & 46.43 & 33.77 & 0.00 & 0.00 \\
\hline & & Cumulative\% & & 19.81 & 66.23 & 100.00 & 100.00 & 100.00 \\
\hline
\end{tabular}




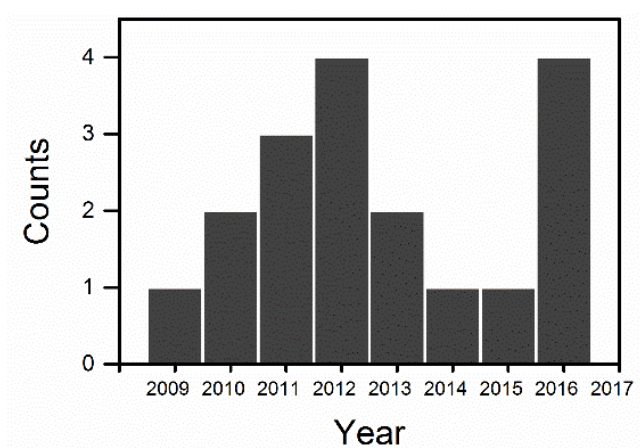

Figure S1. Temporal distribution of soil water repellency about data collection
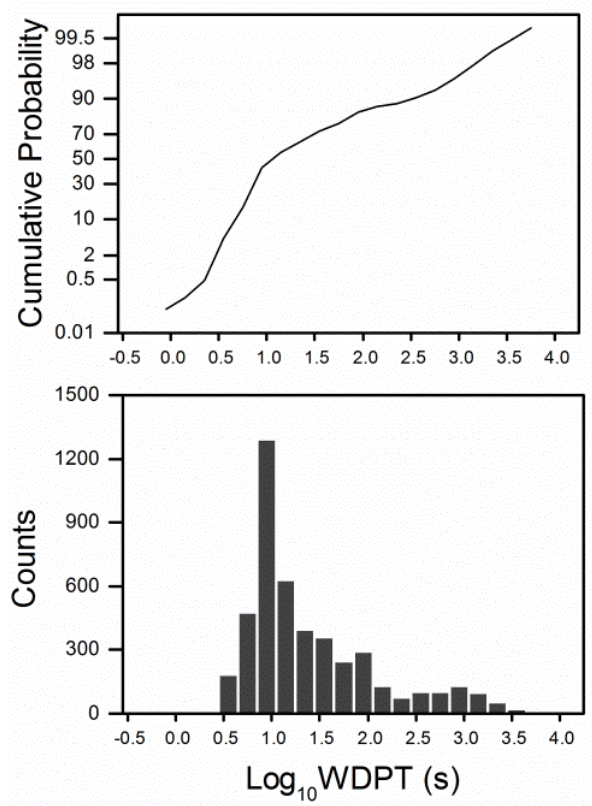

Figure S2. Summary frequency distribution and cumulative probability characteristics of Log10 $\operatorname{WDPT}(s)$

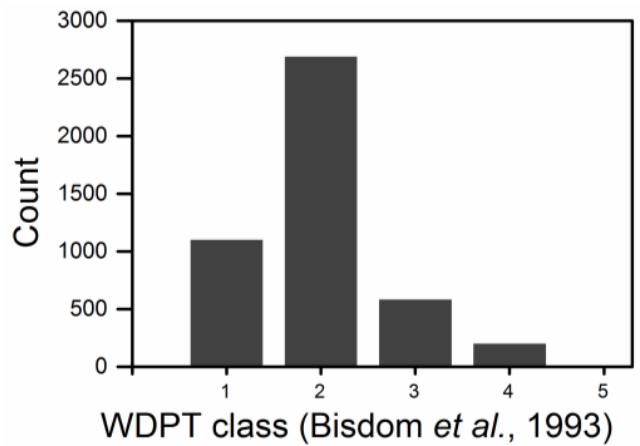

Figure S3. Summary frequency distribution characteristics of five WDPT classes (Bisdom et al., 1993). 1: wettable soil (WDPT $<5$ s); 2:slightly water repellent (WDPT range 5-60s);

3:strongly water repellent (WDPT range 60-600s) 4:severely water repellent (WDPT range 600-3600s) 5:extremely water repellent (WDPT>3600s) 